\title{
Angular Diameters (bimba) of the Sun, Moon and Earth's Shadow-cone in Indian Astronomy: A Comparative Study
}

\author{
S Balachandra Rao*, M Shailaja** and V Vanaja***
}

(Received 01 December 2015; revised 17 January 2016)

\begin{abstract}
In the procedures for computing solar and lunar eclipses the angular diameters (bimba) of the eclipsing and the eclipsed bodies play a very important role. The possibility of an eclipse as also its duration depend on these parameters. In classical Indian astronomical texts procedures for the bimbas are given in various forms in different texts. Most texts give the bimbas in terms of the true daily motions of the Moon and the Sun (MDM and SDM). But, some others - including sārin̄is (astronomical tables) determine the bimbas as functions of other parameters viz., the duration of the running naksatra or the manda anomalies of the Sun and the Moon. In the present paper, a comparative study of the various procedures given in different texts is attempted.
\end{abstract}

Key words: Angular diameters, Bimba, Grahalāghava Karaṇakutūhala, Makaranda sāriṇī, Sārin̄ī, Shadow-cone, Sūryasiddhānta,

Abbreviations: In what follows we use the following multi-lettered notations for conveniences of easy identification and computer programming.

SDIA: the Sun's diameter, MDIA : the Moon's diameter, SHDIA : Diameter of the earth's shadow-cone at moon's orbital plane, $S T M D$ : the Sun's true daily motion, MTDM : the Moon's true daily motion.

\section{INTRODUCTION}

It is well-known that in the computations of solar and lunar eclipses the angular diameters (bimba) play a crucial role. In fact these parameters along with the celestial latitude (śara) of the Moon determine the possibility of an eclipse as also its duration. Of course the Sun and the Moon need to be in conjunction for a solar eclipse and in opposition for a lunar eclipse.

In the Indian context a systematic development in the study and use of the angular diameters of the participating bodies is perceptible right from the pre-Āryabhatan time upto the period of the Kerala contribution. In the following sections we present the results of a few classical Indian astronomical texts one by one and compare them.

\section{Diameters of the Sun, Moon and \\ Earth's Shadow-CONE aCcording to SŪRYASIDDHĀNTA (SS)}

sārdhāni șaṭ sahasrāṇi yojanāni vivasvataḥ|

* Hon. Director, Gandhi Centre of Science and Human Values, Bharatiya Vidya Bhavan, \#43/1, Race Course Road, Bengaluru-560001. E-mail:balachandra1944@gmail.com

** Assistant Professor, Department of Mathematics, Government First Grade College, Vijayanagara, Bengaluru-560104. Email ID: shaila.ac55@yahoo.com

*** Assistant Professor, Department of Mathematics, Government First Grade College, Frazer Town, Bengaluru-560005. Email ID: vanajaksr94@yahoo.com 
viṣkambho maṇdalasyendoḥ sāsítiștu catuśśatam

sphuțasvahuktyā guṇitau madhybhuktyoddhrtau sphuțau \|

SS, ch-IV, 1-2

The (mean) diameters of the Sun and the Moon are respectively 6500 and 480 yojanas. These are multiplied by their individual true daily motions and divided by the mean daily motions to get the true diameters (in yojanas).

The popular classical text Süryasiddhānta gives expressions for the angular diameters of the eclipsing (chädaka) and the eclipsed (chādya) bodies in terms of yojanas (linear units) as follows.

\section{(i) Sun's diameter (Ravi bimba):}

$$
S D I A=\left(\frac{S T D M \times 6500}{S M D M}\right) \times\left(\frac{S \cdot \text { Revns }}{M \cdot \text { Revns }}\right)
$$

where S.Revns and M.Revns are respectively the revolutions of the Sun and the Moon in a mahãyuga of $432 \times 10^{4}$ years. The remaining variables are explained earlier in Abbreviations. Here the text takes the Sun's linear diameter as 6500 yojanas.

\section{(ii) Moon's diameter (Candra bimba):}

$$
M D I A=\left(\frac{M T D M \times 480}{M M D M}\right) \text { yojanas }
$$

where $M T D M=$ the Moon's true daily motion, $M M D M=$ the Moon's mean daily motion. Moon's linear diameter is taken as 480 yojanas.

(iii) Diameter of Earth's shadow-cone (Bhūcchāy $\bar{a}$ bimba):

$$
\begin{aligned}
\text { SHDIA } & =\left(\frac{M T D M \times 1600}{M M D M}\right) \\
= & {\left[(S D I A-1600) \times \frac{480}{6500}\right] \text { yojanas } }
\end{aligned}
$$
in yojanas.

where 1600 is the earth's linear diameter

The true daily motions of the Sun and the Moon, STDM and MTDM vary with their respective manda anomalies (mandakendra, $M K$ ). The variation of the Sun's true daily motion with its $M K$ is given by

$$
\begin{aligned}
& \text { STDM }=59.1388-(1.98109) \cos (M K) \\
& -(0.041285) \cos (2 M K) \\
& \text { in kalās (arc min.) }
\end{aligned}
$$

Here, manda anomaly

$M K=$ Sun's Mandocca (Apogee) - Mean Sun

Similarly, the Moon's true daily motion, in terms of its manda anomaly $M K$ is given by

$$
M T D M=790.5666-\left(\frac{P R D}{360}\right)
$$

$\times 783.9 \times \cos (M K)$ in kalās (arc min.)

where $P R D$ is the Moon's manda paridhi (periphery). Here also, $M K=$ Moon's Mandocca (Apogee) - Mean Moon

From (2.4) and (2.5), as $M K$ varies from $0^{0}$ to $360^{\circ}$, the minimum values of the true daily motions $(T D M)$ of the Sun and the Moon are as shown in Table 2.1.

Table 2.1: Minimum and maximum true daily motions.

\begin{tabular}{|c|c|c|}
\hline Body & $\begin{array}{c}\text { Minimum } \\
T D M\end{array}$ & $\begin{array}{c}\text { Maximum } \\
T D M\end{array}$ \\
\hline Sun & $56^{\prime} .83$ & $61^{\prime} .43$ \\
\hline Moon & $720^{\prime} .8866$ & $860^{\prime} .2466$ \\
\hline
\end{tabular}

The variations of the Sun's true daily motion (STDM) and its diameter (Ravi bimba) SDIA with $M K$ are shown in Table 2.2.

Table 2.2: Variations of STDM and SDIA with Sun's $M K$.

\begin{tabular}{|c|c|c|}
\hline$M K(\mathrm{Deg})$ & STDM (Min) & SDIA (Min) \\
\hline 0 & 56.83 & 31.24 \\
\hline 30 & 57.19 & 31.44 \\
\hline 60 & 58.03 & 31.90 \\
\hline 90 & 59.13 & 32.51 \\
\hline 120 & 60.24 & 33.11 \\
\hline 150 & 60.84 & 33.44 \\
\hline 180 & 61.43 & 33.77 \\
\hline
\end{tabular}

Similarly the variations of the Moon's true daily motion (MTDM) and its diameter 
(MDIA, Candra bimba) are shown in Table 2.3.

Table 2.3: Variations of MTDM and MDIA with Moon's $M K$.

\begin{tabular}{|c|c|c|}
\hline$M K($ Deg $)$ & $M T D M(M i n)$ & MDIA (Min) \\
\hline 0 & 720.89 & 28.89 \\
\hline 30 & 730.85 & 29.28 \\
\hline 60 & 756.35 & 30.31 \\
\hline 90 & 790.57 & 32.68 \\
\hline 120 & 824.78 & 33.05 \\
\hline 150 & 850.28 & 34.07 \\
\hline 180 & 860.25 & 34.47 \\
\hline
\end{tabular}

The angular diameter of the earth's shadow-cone (bhücchāyā bimba, SHDIA) varies with the true daily motions of both the Sun and the Moon (STDM and MTDM). While STDM varies from the minimum of $56^{\prime} .83$ to the maximum of $61^{\prime} .43$, the corresponding extrenal values of $M T D M$ in the case of the Moon are respectively $720^{\prime} .8866$ and $860^{\prime} .2466$ (see Table 2.1).

Table 2.4: SHDIA according to Karañakutūhala

\begin{tabular}{|c|c|c|c|c|c|c|}
\hline $\begin{array}{c}S T D M \rightarrow \\
M T D M \downarrow\end{array}$ & $57^{\prime}$ & $58^{\prime}$ & $59^{\prime}$ & $60^{\prime}$ & $61^{\prime}$ & $62^{\prime}$ \\
\hline 720 & 72.3 & 71.9 & 71.4 & 71 & 70.6 & 70.1 \\
\hline 730 & 73.6 & 73.2 & 72.8 & 72.3 & 71.9 & 71.5 \\
\hline 740 & 75 & 74.5 & 74.1 & 73.7 & 73.3 & 72.8 \\
\hline 750 & 76.3 & 79.5 & 75.5 & 75 & 74.6 & 74.2 \\
\hline 760 & 77.7 & 77.2 & 76.8 & 76.4 & 75.9 & 75.5 \\
\hline 770 & 79 & 78.6 & 78.1 & 77.7 & 77.3 & 76.9 \\
\hline 780 & 80.3 & 79.9 & 79.5 & 79.1 & 78.6 & 78.2 \\
\hline 790 & 81.7 & 81.3 & 80.8 & 80.4 & 80 & 79.5 \\
\hline 800 & 83 & 82.6 & 82.2 & 81.7 & 81.3 & 80.9 \\
\hline 810 & 84.4 & 83.9 & 83.5 & 83.1 & 82.7 & 82.2 \\
\hline 820 & 85.7 & 85.3 & 84.9 & 84.4 & 84 & 83.6 \\
\hline 830 & 87.1 & 86.6 & 86.2 & 85.8 & 85.3 & 84.9 \\
\hline 840 & 88.4 & 88 & 87.6 & 87.1 & 86.3 & 86.3 \\
\hline 850 & 89.8 & 89.3 & 88.9 & 88.5 & 88 & 87.6 \\
\hline 860 & 91.1 & 90.7 & 90.2 & 89.8 & 89.4 & 89 \\
\hline 870 & 92.4 & 92 & 91.6 & 91.2 & 90.7 & 90.3 \\
\hline
\end{tabular}

We have listed in Table 2.4 the values of the diameter of the earth's shadow-cone (SHDIA) for $M T D M$ from $720^{\prime}$ to $860^{\prime}$ and $S T D M$ from $57^{\prime}$ to 62 'respectively. According to the Karanakutūhala of Bhāskara II (epoch 1183 C.E.)

We notice from Table 2.4 that the diameter of the earth's shadow-cone SHDIA is minimum at $70^{\prime} .1$ for the minimum $M T D M=720^{\prime}$ and the maximum $S T D M=62^{\prime}$. Similarly, $S H D I A$ is maximum at $92^{\prime} .4$ for the maximum $M T D M=870^{\prime}$ and minimum $S T D M=57^{\prime}$.

\section{Sun's Diameter aCcording to Other TEXTS}

It is interesting to compare the expressions and the values of the Sun's angular diameter according to a few other Indian astronomical texts.

Gạ̣ eśa Daivajña $(1520 \mathrm{CE})$ in his Grahalāghava mentions:

vyasuśaragatīṣvamśo digyugbhavedvapuruṣnagor atha sitaruco bimbạ̣ bhuktiryugācalabhājitā |

tadapi himagorbimbam trighnam nijeśalavānvitam vivasu bhvati kṣmābhābimbaṃ kilānigulapūrvakam \||

$$
\text { - GL, ch-V, } 3
$$

From the Sun's daily motion (in kalās) 55 is subtracted, the difference is divided by 5 and the result is added to 10 , giving the Sun's diameter in angulas. The Moon's daily motion (in kalās) divided by 74 gives the Moon's diameter in angulas. 3 times the Moon's diameter (in angulas) divided by 11 is add to 3 times the Moon's diameter; from the result subtract 8 to get the diameter of the earth's shadow-cone ( $b h \bar{u}-b h \bar{a})$.

The above procedures are used in what follows under separate heads.

(i) From the above we have the following expression for the Sun's diameter:

$$
\text { SDIA }=\left(\frac{S T D M-55}{5}\right)+10 \text { angulas }
$$


where STDM is Sun's true daily motion in kalās.

An angula $=3$ kalās (arc minutes).

(ii) Brahmagupta in his karana text (handbook), Khaṇdakhādyaka (KDK) provides

bhavadaśagunite ravi śaśigatī nakhaị svarajinairhrte māne |

șaștyā bhaktam tatvā'ṣtaguṇitayōrantaram tamasah ||

- KDK, ch-IV, 2

The true daily motions of the Sun and the Moon multiplied respectively by 11 and 10 , and divided by 20 and 247, give their angular diameters in minutes. The difference between 8 times the true motion of the moon and 25 times that of the Sun, when divided by 60 gives the angular diameter of the earth's shadow in minutes.

i.e. $S D I A=S T D M \times\left(\frac{11}{20}\right)$ kalās

(iii) In the southern part of India a popular system of astronomical computations prevalent is the Vākya Paddhati. In this system the true positions of planets, using their synodic and anomalistic periods, are given in the form of simple meaningful Sanskrit sentences (vākyas). Here each letter of a given sentence represents a number following the katapayādi system of letter numerals. The popular text in this genre, Vākya karaṇa obtains Sun's diameter from the expression ${ }^{1}$

$S D I A=S T D M \times\left(\frac{5}{9}\right) k a l \bar{a} S$

(iv)The famous commentator Viśvanātha Daivajña (c.1620 C.E.) in his Udāharana gloss on $G L$ computes the Sun's diameter from the expression

$S D I A=S T D M \times(2 / 11)$ angulas

For the purpose of comparison the values of the Sun's angular diameter according to the above different texts forthe increasing anomaly (from the apogee) arecomputed and presented in Table 3.1 at intervals of $20^{\circ}$ of Sun's anomaly. These are compared with the values obtained from modern computations.

From Table 3.1 we observe that the values of Bhāskara II and Viśvanātha differ the least from the corresponding modern values while those of the Văkya system differ the maximum.

Table 3.1: Sun's Diameter according to different Texts.

\begin{tabular}{|c|c|c|c|c|c|}
\hline MK (Deg) & Grahaläghava & Khaṇdakhädyaka & Vākya & $\begin{array}{c}\text { Bhāskara II } \\
\text { and } \\
\text { Viśvanātha }\end{array}$ & Modern \\
\hline 0 & 31.27 & 31.41 & 31.73 & 31.15 & 31.50 \\
\hline 20 & 31.35 & 31.49 & 31.8 & 31.22 & 31.54 \\
\hline 40 & 31.57 & 31.69 & 32.0 & 31.43 & 31.63 \\
\hline 60 & 31.90 & 31.99 & 32.32 & 31.73 & 31.77 \\
\hline 80 & 32.30 & 32.36 & 32.69 & 32.09 & 31.95 \\
\hline 100 & 32.71 & 32.74 & 33.07 & 32.47 & 32.13 \\
\hline 120 & 33.09 & 33.08 & 33.43 & 32.81 & 32.31 \\
\hline 140 & 33.39 & 33.36 & 33.69 & 33.08 & 32.45 \\
\hline 160 & 33.58 & 33.53 & 33.87 & 33.26 & 32.54 \\
\hline 180 & 33.65 & 33.59 & 33.93 & 33.32 & 32.58 \\
\hline
\end{tabular}

1. Vākya pañcādhyāȳī, Cr.Ed.by T.S. Kuppanna Śastri and K.V. Śarma, KSR Inst., Madras, 1962. Chaper IV, page number 95 and 96 


\section{Moon's Diameter According to Different TeXts}

(i) Brahmagupta's Khạ̣ ḍakhādyaka (epoch March 23, 665 C.E.) gives the following expression for MDIA [sec 3 ii)

$M D I A=\frac{10}{247} \times M T D M$

The rationale for the above expression is provided by taking

$$
\begin{gathered}
M D I A=\text { Mean diameter } \times\left(\frac{\text { MTDM }}{\text { MMDM }}\right) \\
=\left(\frac{\mathbf{3 2}^{\prime}}{\mathbf{7 9 0}^{\prime} \mathbf{3 1}^{\prime \prime}}\right) \times M T D M \\
=\left(\frac{\mathbf{1}}{\mathbf{2 4 . 7 0 3 6}}\right) \times M T D M \\
\approx\left(\frac{10}{247}\right) \times M T D M
\end{gathered}
$$

(ii) According to Grahalāghava of Ganeśa Daivajña, the Moon's bimba

$$
\begin{aligned}
\text { MDIA }= & \left(\frac{M T D M}{74}\right) \text { angulas } \\
& =\frac{3}{74} \times \text { MTDM kalās }
\end{aligned}
$$

(iii) According to the Vākya system

$$
\text { MDIA }=\left(\frac{M T D M}{25}\right) k a l \bar{a} s
$$

\section{Diameter of the Earth's Shadow-cone ACCORDING TO OTHER TEXTS}

(i) Khandakhādyaka provides the following expression. [sec 3 ii)

$$
\text { SHDIA }=\left(\frac{8 \times M T D M-25 \times \text { STDM }}{60}\right) \text { kalās } \ldots .
$$

(ii) Lalla's in his Śiśyadhī-vrddhi-da calculates SHDIA using the formula:

$$
\text { SHDIA }=\left(\frac{2 \times M T D M}{15}\right)-\left(\frac{11}{20}-\frac{2}{15}\right) \times \text { STDM kalās }
$$

(iii)In the $V \bar{a} k y a$ system the expression for $S H D I A$ is given as follows:

$$
\text { SHDIA }=\left(\frac{5}{2}\right) \times \text { MDIA kalās }
$$

(iv) Gaṇeśa Daivajña’s Grahalāghava (1520 CE)

$$
\text { SHDIA } \left.=\left(\frac{3}{11}\right) \times M D I A+3 \times M D I A\right)-8 \text { angulas }
$$

(v) Viśvanātha in his commentary on Grahalāghava modifies the formula for SHDIA as

$$
\text { SHDIA }=\left(\frac{M T D M}{22}\right)-\left(\frac{\text { STDM }}{7}\right)-\left(\frac{6}{11}\right) \text { angulas }
$$

Table 5.1: Minimum and maximum SHDIA

\begin{tabular}{|c|c|c|}
\hline Text & $\begin{array}{c}\text { Min. SHDIA } \\
(\text { kalās })\end{array}$ & $\begin{array}{c}\text { Max. SHDIA } \\
(\text { kalās })\end{array}$ \\
\hline Khaṇdakhādyaka & 70.17 & 92.67 \\
\hline Śiśyadhī-vrddhi-da & 70.2 & 92.7 \\
\hline Vākya & 73.5 & 86 \\
\hline Grahalāghava & 71.53 & 90.1 \\
\hline Udāharana & 70.0 & 93 \\
\hline
\end{tabular}

In the Vākya system as well as in the Grahalāghava the diameter of the shadow-cone is given only in terms of MDIA. From Table 5.1 we observe that the range of the variation of the shadow's diameter is widest from $70^{\prime}$ to $93^{\prime}$ in the case of Viśvanātha's procedure. On the other hand, in the Vākya system, the range is narrowest from $73^{\prime} .5$ to $86^{\prime}$.

Actually the shadow-cone depends directly on the motions and the relative distances of both the Sun and the Moon. This fact has been taken into account by Brahmagupta, Lalla and Viśvanātha. The values of SHDIA according to modern procedure varies from $76^{\prime} .67$ to $93^{\prime} .02$. The minimum angular diameter $76^{\prime} .67$ is attained when the Sun's anomaly is $0^{0}$ and the Moon's anomaly is $180^{\circ}$. Similarly the maximum angular diameter $93^{\prime} .02$ when the Sun's anomaly is $180^{\circ}$ and the Moon's anomaly is $0^{\circ}$. Here the anomalies are measured from the respective perigees.

Interestingly Copernicus (1473- 1543) in his De Revelutionibus gives the ratio of the diameter of the earth's shadow-cone to that of the Moon as $k=\frac{403}{150}=2.6866$. Thus, the text gives the greatest and the least diameters as

$$
\begin{aligned}
& d_{\min }=k \times 0^{0} 30^{\prime} \quad=1^{0} 20^{\prime} 36^{\prime \prime}=80^{\prime} 36^{\prime \prime}{ }^{\prime} \\
& d_{\max }=k \times 0^{0} 35^{\prime} 38^{\prime \prime}=1^{0} 35^{\prime} 44^{\prime \prime}=95^{\prime} 44^{\prime \prime}{ }^{\prime}
\end{aligned}
$$




\section{According to Bhāskara's Karanakutūhala Diameters of Sun, Moon and Earth's Shadow-CONE}

Bhāskara II gives the expression for these angular diameters in the following śloka in his Karanakutūhala (KRK)

bimbạ̣ vidhoḥ syāt svagatir yugādri bhaktā

raverdasrahatā śivāptā||

trighnīndubhuktis turagānigabhaktā

bhūbhārka bhuktyādri lavenahīnā|

$-K R K$, ch-IV,7,8

The Moon's (angular) diameter (bimbam) is its (daily) motion divided by 74, (the diameter) of the Sun is that (its daily motion) multiplied by 2 and divided by 11 . The shadow's diameter $(b h \bar{u}-b h \bar{a})$ is the Moon' daily motion multiplied by 3 and divided by 67 reduced by one-seventh of the Sun's motion.

This means

(ii) $S D I A=\frac{S T D M \times 2}{11}$ angulas angulas

(iii) $S H D I A=\left(M T D M \times \frac{3}{67}\right)-\left(S T D M \times \frac{1}{7}\right)$

Example: Lunar eclipse dated śaka 1542, Mārgaśīrșa śukla 15 (paurṇimā), Wednesday, corresponding to December 9, $1620 \mathrm{CE}(\mathrm{G})$. $829^{\prime} 35^{\prime \prime}$

That day, $S T D M=61^{\prime} 21^{\prime \prime}$ and $M T D M=$

Therefore,

(i) $S D I A=61^{\prime} 21^{\prime \prime} \times \frac{2}{11}=11 \mid 09$ aing

(ii) $M D I A=\frac{829^{\prime} 35^{\prime \prime}}{74}=11 \mid 12 \mathrm{ang}$

(iii) $S H D I A=829^{\prime} 35^{\prime \prime} \times \frac{3}{67}-61^{\prime} 21^{\prime \prime} \times \frac{1}{7}=$ $28 \mid 22$ ang

\subsection{Rationale for the bimbas:}

It is assumed that the angular diameter is proportional to the true daily motion of a body and given by
True $b i m b a=$ Mean bimba $\times \frac{\text { True daily motion }}{\text { Mean daily motion }}$

(i) In the case of the Moon, the mean daily motion is 790', taking the Moon's mean angular diameter as close to 32' (see P.C Sengupta (1934)), we have the Moon's true diameter (MDIA) given by

$$
\begin{aligned}
& \text { MDIA }=\frac{32^{\prime} \times M T D M}{790^{\prime}} \text { kalās } \\
& \quad=\frac{\text { MTDM }}{\left(\frac{790 \times 3}{32}\right)}=\frac{\text { MTDM }}{74.0625} \text { aig }
\end{aligned}
$$

where MTDM is the Moon's true daily motion. Bhāskara II has taken the denominator as 74.

(ii) For the Sun, the mean daily motion is $59^{\prime} 8^{\prime \prime}$ and taking the Sun's mean angular diameter as 32' 31' (P.C. Sengupta (1934)), we have the Sun's true angular diameter (SDIA) given by

$$
\begin{gathered}
\text { SDIA }=\frac{32^{\prime} 31^{\prime \prime} \times S T D M}{59^{\prime} 8^{\prime \prime}} \text { kalās } \\
=\frac{S T D M}{\left(\frac{59^{\prime} 8^{\prime \prime} \times 3}{32^{\prime} 31^{\prime \prime}}\right)}=\text { aìg }
\end{gathered}
$$

Bhāskara II has taken the denominator as 5.5 i.e., $11 / 2$ so that

$$
S D I A=\frac{2}{11} \times S T D M \text { arg }
$$

where STDM is the Sun's true daily motion.

(iii)The angular diameter of the earth's shadowcone at the Moon's orbit is given by SHDIA $=2 \times\left(p+p^{\prime}-\mathrm{s}\right)$

where $p$ and $p^{\prime}$ are the horizontal parallax of the Sun and the Moon and $s$ is the Sun's angular semi-diameter (see fig 6.1).

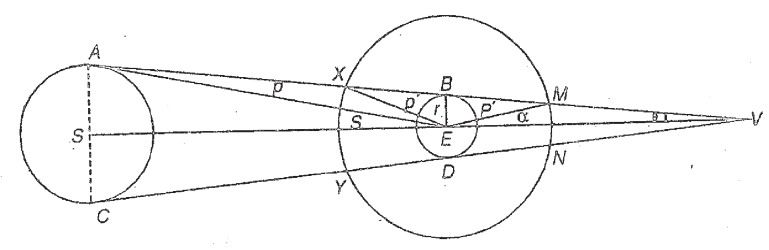

Fig. 6.1: Angular diameter of the Shadow-cone 
In Fig 6.1, the angular diameter of the cross-section of the shadow cone is represented by $\operatorname{arc} M N$. Let the semi-angle $M E V$ subtended by $M N$ at the centre of the earth be $\alpha$.

We have

$p=$ the Sun's horizontal parallax $=E \hat{A} X$

$p^{\prime}=$ the Moon's horizontal parallax $=$ $E \widehat{M} B=E \hat{X} B$

$s=$ the Sun's angular semi-diameter $=S \widehat{E} A$

$\theta=$ semi-vertical angle of the shadow-cone $=E \widehat{V} B$

Now, in triangle $M E V$, we have

$\alpha+\theta=p^{\prime}$ so that $\alpha=p^{\prime}-\theta$

Similarly, we have from the triangle $A E V$,

$$
\theta=s-p^{\prime}
$$

From (6.2) and (6.3) we get,

$$
\alpha=p^{\prime}-(s-p) \text { or } \alpha=p+p^{\prime}-\mathrm{s}
$$

The assumption in siddhāntic texts is that the horizontal parallax of a body is $\left(\frac{1}{15}\right)^{t h}$ of its true daily motion. Accordingly,

$$
p=\frac{M T D M}{15} \text { and } p^{\prime}=\frac{S T D M}{15} \text { in kaläs and the }
$$

Sun's angular diameter $2 s=\frac{6}{11} S T D M$

Substituting these in (6.1), we have

$$
\begin{aligned}
& \text { SHDIA }=2\left[\frac{\text { MTDM }}{15}+\frac{\text { STDM }}{15}-\frac{3}{11} \text { STDM }\right] \text { kalā } S \\
& =2\left[\frac{M T D M}{15}+\left(\frac{1}{15}-\frac{3}{11}\right) \text { STDM }\right] \text { kalās } \\
& =2\left[\frac{\text { MTDM }}{15}+\left(\frac{11-45}{165}\right) \text { STDM }\right] \text { kalās } \\
& =\left[\frac{M T D M}{\left(\frac{15 \times 3}{2}\right)}-\frac{\text { STDM }}{\left(\frac{165 \times 3}{34 \times 2}\right)}\right] \text { aing } \\
& =\frac{\text { MTDM }}{22.5}-\frac{\text { STDM }}{7.279} \text { ang } \\
& =\frac{M T D M \times 3}{67.5}-\frac{\text { STDM }}{7.279} \text { ang }
\end{aligned}
$$

Bhāskara II has taken the two denominators respectively as 67 and 7 .

\section{Conclusion}

In the preceding sections we have discussed the algorithms of diameters (bimbas) of the Sun, Moon and the earth's shadow-cone (bhūcchāy $\bar{a}$ bimba). According tosome classical Indian astronomical texts and the results are compared, where feasible, with those from the modern procedures.

\section{BibliograPHY}

Karañakutūhalam with commentary of Sumatiharșa, Kṛ̣ṇadās Academy, Vāraṇāsi 1991.

Montelle, Clemency, Chasing Shadows, The John Hopkins University Press Baltimore, 2011.

Rao, S.Balachandra and Uma S.K., Karaṇakutūhalam of Bhāskarācārya II, an English Tr. with notes and Appendices, IJHS, 42.1-2 (2007),43.1\&3 (2008), INSA, New Delhi, 2008.

Rao, S. Balachandra, Ancient Indian Astronomy- Planetary Positions and Eclipses, BRPC Ltd., Delhi, 2000.

Rao, S. Balachandra and Uma S.K, Grahalāghavam of Ganeśa Daivajña, an English Exposition with Mathematical Explanation, Derivations, Examples, Tables and Diagrams.Indian National Science Academy New Delhi. Reprinted from IJHS 41.1-4 (2006).

Rao, S Balachandra, Indian Astronomy---Concepts and Procedures, M P Birla Institute of Management, Benguluru, 2014.

Sūryasiddhānta, (i) Ed. Kripa Shankar Shukla, Lucknow University, 1957 (ii) Ed. Ramchandra Pandeya, Chaukhamba Surabharati Prakashan, Varansi, 2001.

Śastri T.S. Kuppann and Śarma, K.V(ed.) Vākya pañcādhyāȳì, KSR Institute, Madras, 1962.

Smart,W.M., Textbook on Spherical Astronomy, Vikas Publishing House Pvt. Ltd., New Delhi, 1979.

Sengupta, P.C (Ed. and Tr.) Khan ḍakhādyakam of Brahmagupta,Calcutta,1934. 